UDC 664.68:637.142.2]:613.2-053.9

DOI: 10.31866/2616-7468.2.1.2019.170407

\title{
INNOVATIVE GERO-DIETETIC CONFECTIONERY PRODUCTS TECHNOLOGY WITH USING SECONDARY DAIRY RAW FOOD
}

Karyna Svidlo,

Doctor of Engineering Sciences, Kharkiv Institute of Trade and Economics of Kyiv National University of Trade and Economics, Kharkiv, Ukraine, karinasvidlo@gmail.com http://orcid.org/0000-0002-0175-7756 () Свідло К., 2018

Actuality. The process of creating a new branch of food industry for gero-dietetic products is important in some aspects: wide introduction of gero-dietetic products in the actual food for elderly and old people will enable us to correct the nutrition of contemporary people; the use of gero-dietetic products is extremely important for medical nutrition and prevention of premature aging. Purpose and methods. The purpose of the article is to ground the use of whey proteins concentrate obtained by ultrafiltration with fructose in the gero-dietetic confectionery technology. The method of raw glutent quantity and quality used in the research satisfies ISO 21415-2:2015 wheat and wheat flour - Gluten content - Part 2: determination of wet gluten and gluten index has been identified by mechanical means. Dough mass adhesive tension dependence on various concentrations of the model system WPS-UF: fructose was carried out in the tension testing mashine MT-140/ RV2. Results. The research data for whey proteins concentrate obtained by ultrafiltration (WPC-UF) with fructose on the cake dough properties awas obtained and innovation technology for gero-dieteric cakes on the basis of these data was developed. Conclusions and discussion. The use of whey proteins concentrate obtained by ultrafiltration with fructose in the confectionary technology makes it possible to have products which satisfies the formula of gero-dietetic food.The developed gero-dietetic cakes can be used for oversixty-year-old people for ilness prevention, as well as for general health improvement.

Keywords: gero-dietetic products, technology of confectionery products, secondary dairy raw materials, whey proteins concentrate obtained by ultrafiltration (WPC-UF), fructose.

\section{Actuality of problem}

The problem formulation. The process of creating the new branch of food industry for gero-dietetic products is important in some aspects: wide introduction of gerodietetic products in the actual food for elderly and old people to correct nutrition of contemporary people; the use of gero-dietetic products is extremely important as medical nutrition not only for this sections of the population but for younger age groups with the aim of premature aging prevention (Cherevko, 2017).

Normal organism functioning and optimal rate of exchange processes in the middle and old age requires regular protein supply, namely diary products. The consumption in adequate and balanced diet for aged people is known not to be more than $20 \mathrm{~g}$ flour, $30 \mathrm{~g}$ sugar, $2 \mathrm{~g}$ starch, $20 \mathrm{~g}$ vegetable oil, and $14 \mathrm{~g}$ aggs per day (Hryhorov et al., 2006). Nevertheless, the analysis of chemical composition and food value of flour confectionary products shows that prevailing number of them does not meet the requirements of gero-dietetics. The composition of flour confectionary products is unballanced due 
to high content of fat, carbohydrates and relatively low protein, food fibres, unsaturated fatty acids, vitamins.

Development and making of innovative products which meet the requirements of gero-dietetics for composition and formula are the most effective in this situation.

The study state. Flour confectionary products are very important in the diet and are ndispensable in the Ukrainian cuisine. They have high calorie content, assimilability, low moisture content, good flavour, delicate odor and are attractive to look at; all this accounts for their high taste values. Caloric value of these products at the rate of $100 \mathrm{~g}$ product varies from 1200 to $2300 \mathrm{~kJ}$. It accounts for high content of digestable carbohydrates, fats and proteins (Lysiuk, 2009).

The dough cake half-finished product is a multi-phase structured system which consists of solid and gaslike phases and foresees the structure air phase which provides porosity. To make thin emulsion, egg products are insufficient; therefore emulsifier is used. It "crashes" fat into tiny balls, prevents them from adhesion, thus stabilizing emulsion. The smaller fat particles, the better they are distributed between dough particles, creating thin films, which prevent binding water with dough proteinsub stances (Lysiuk, 2007).

As a result, baking process creates proper cake structure and the product acquires tender finely porous consistence; besides, fat migration onto product topping is decreased. By creating thin fat films, emulsifier decreases friction between formulation mixture components. This increases dough plasticity and decreases its sticking to the equipment working parts.

Chemical baking powders $\mathrm{NaHCO}_{2}$ (household soda) and $\left(\mathrm{NH}_{4}\right)_{2} \mathrm{CO}_{3}$ (carbonic ammonium) are used for leavening dough. They are used as leave because temperature dessociates them into gaseous products and leaven the dough.

Carbonic ammonium under high temperature dissociates into carbonic gas, water and alkaline salt:

$$
2 \mathrm{NaHCO}=\mathrm{CO}_{2}+\mathrm{H}_{2} \mathrm{O}+\mathrm{Na}_{2} \mathrm{CO}_{3}
$$

Alkaline salt $\mathrm{Na}_{2} \mathrm{CO}_{3}$, when used in a high proportion, worsens product taste and aroma; that's why household soda is partly replaced by carbonic ammonium.

Affected by high temperature of the baking goods, ammonium is dissociated into carbonic gas, ammonia and water:

$$
\left(\mathrm{NH}_{4}\right)_{2} \mathrm{CO}_{3}=2 \mathrm{NH}_{3}+\mathrm{CO}_{2}+\mathrm{H}_{2} \mathrm{O}
$$

As a result of kneading, the homogenous mass of dough, water and other components is obtained; it has such specific physical properties as springing, elasticity and tensility. The mechanism of dough formation may be represented this way. Adding water to flour promotes swelling of its colloids - protein substances and starch, which are found in flour as dry gels. In the process of protein swelling, about a quarter of all absorbed water is bound by absorption; the rest of it is done osmatically (Svidlo, 2010). Protein swelling after dough kneading takes 20-30 minutes. Colloid aggregations are being formed - gluten, which is important for formation of dough physical properis. Hydrated protein substances set up the spongelike framework, add the dough tensility and elasticity. 
Thus, existing recipes of cakes don't meet the requiremnts of gero-dietetic food. That's why we need to introduce confectionary foods approaching in their composition to the ideal producs as to the gero-dietetic requiremqnts.

Outstanding issues. Calcium which is involved in the formation of bone tissue is essentual for the diet of elderlyy people. Calcium digestion depends on its balance with other food nutrients, first of all with phosphorus.The most reasonable ratio of $\mathrm{Ca}: \mathrm{P}$ is $1: 1.5$. The ratio of $\mathrm{Ca}: \mathrm{Mg}$ must be 1:0.5. Magnium acts in zymogenic processes and has vasodilating and diuretic effect (Morley, \& Thomas, 2007). Taking all this into consideration, we proposed the technology of preparing gero-dietetic muffins with secondary diary raw materials i.e. whey proteins concentrate obtained by ultrafiltration (WPC-UF) with fructose.

WPC-UF contains all necessary amino acids and easily digested. It contains all nine essentual amino acids which must come with food, has excellent water-binding and stabilizing properties, has good water adsorption and gelatinization, excellent solubilitty in a wide range of $\mathrm{pH}$, and improves structure and consistency, adds cream taste to the product (Rostovskyi, Dorokhyna, \& Polozhyshnykova, 1988).

\section{Purpose and research methods}

Purpose of the article. The purpose of the article is to ground the use of whey proteins concentrate obtained by ultrafiltration with fructose in the gero-dietetic confectionery technology.

Methodology basis of research is the study of confectionary gero-dietetic goods using whey proteins concentrate obtained by ultrafiltration with fructose. The basis of the research of the above-mentioned composition is the method of raw glutent quantity and quality in accordance with ISO 21415-2:2015 Wheat and wheat flour Gluten content - Part 2: determination of wet gluten and gluten index by mechanical means and the method of determining dough adhesion tension in the tension testing mashine MT-140/ RV2.

Research methods: physico-chemical, stuctural physical, statistical, which helped to estimate the influence of the whey protein concentrate obtained by ultrafiltration with fructose on muffin dough properties.

Information base of reseaech: monograph, training manuals, scientific articles, materials of international symposiums, theoretical and practical conferences.

\section{Research results}

Preparing half-finished muffins requiews dough with medium gluten content; larger quqntities can result in low organoleptic characteristics (the product will be nonporous and heavy). To find the behaviour of gluten changing properties using whey dourh with WPC-UF, studies have been carried out on model systems with varying additive portions (from 1 to 40\%). The wheat gluten, which was washed off dough, was taken as a control check; the dough was made according to the standard methods.

The WPC-UF introducing concentration ratio was carried out on the quantitative and qualititave (strech) studies of raw gluten (Fig.1) within concentration values $0-40 \%$ at the ingredient ratios of WPC-UF: fructose 1:1 (Diagram 1) and within the range of concentrations $0-40 \%$ at the ingredient ratios of WPC-UF: fructose 1:2 
(Diagram 2). While analysing the data presented in the Fig. 1, it is necessary to note that with concentrations $0-15 \%$, gluten quantity does not cignificantly change. Within $15-30 \%$ adding range, gluten quantity decreases by $25 \%$ in the case of introducing WPC-UF: fructose 1:1; in the case of introducing WPC-UF: fructose 1:2 it decreases only by $5 \%$. At the range of 30-40\% eddings, the decrease of gluten at the ingredient ratios of WPC-UF: fructose $1: 2$ is $49 \%$ relative to the control gluten quantity; in the case of joint introductions of WPC-UF: fructose 1:1 the glutenr content decreases by $30 \%$ relative to the control specimen.

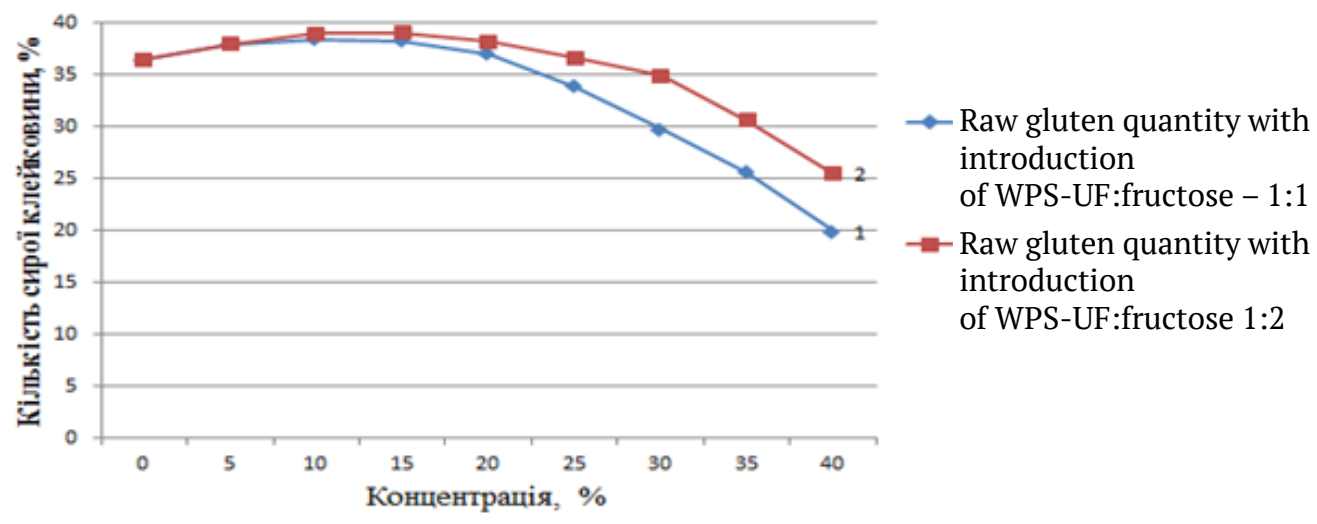

Fig. 1. Raw gluten depending on the concentration of:

1 - WPC-UF: fructose - 1: 1, 2-WPC-UF: fructose - 1: 2 in the dough

Source: own development

Increasing WPC-UF: fructose 1:1does not significantly influence the gluten quality, that is the stretch is more than $20 \mathrm{~cm}$, which characterizes gluten as being long with WPC-UF: fructose $1: 1$ additives for concentrations from 0 to $15 \%$ and from 0 to $25 \%$ with additives of the WPC-UF: fructose 1:2. In the case of maximum additives (40\%) there observed a decrease in gluten stretch to $10 \mathrm{~cm}$, which characterises gluten as average (Fig.2). Such gluten quality is satisfactory for making muffins, which are typical of the English baked goods (breakfast muffins).

In the food industry, the interaction of products with different surfaces is of great importance in the production of half-finished goods, finished goods, their packing and storage. Adgesion is a bonding between heterogenous substances, which condenses with molecule contactes; it studies food substance coherence with surfaces of the technological equipment (containers, conveyers, pipelines, fittings, weight), comes out as a side phenomenon with practically all food masses. Contact intensity between food disperse systems and the serfice depends on some factors.

To determine adhesion we used a control specimen (traditional muffin dough recipe) and dough specimens of modelled product with various concentration of the WPC-UF: fructose system for ithe ingredient ratio 1:2:

- specimen \#1-5\% WPC-UF: fructose

- specimen $\# 2-7.5 \%$ WPC-UF: fructose

- specimen $\# 3-10 \%$ WPC-UF: fructose. 
Ресторанний і готельний консалтинг. Інновації. 2019 Том 2 № 1

Restaurant and hotel consulting. Innovations. 2019 Vol. 2 No 1

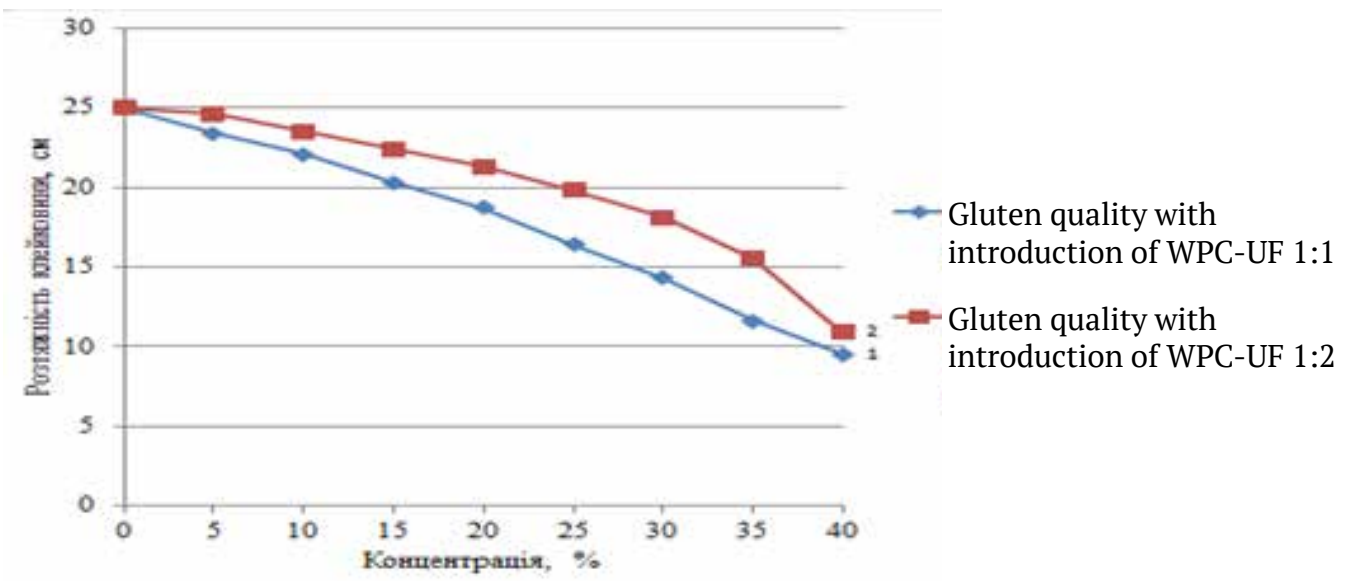

Fig. 2. Gluten stretch (quality) depending on the concentration of 1 - WPC-UF: fructose - 1: 1, 2-WPC-UF: fructose - 1: 2 in the dough

Source: own development

The dependence of dough adhesion tension on the influence of various concentrations of the model WPC-UF: fructose system has been determined (Table 1). The data are shown graphically in Fig. 3.
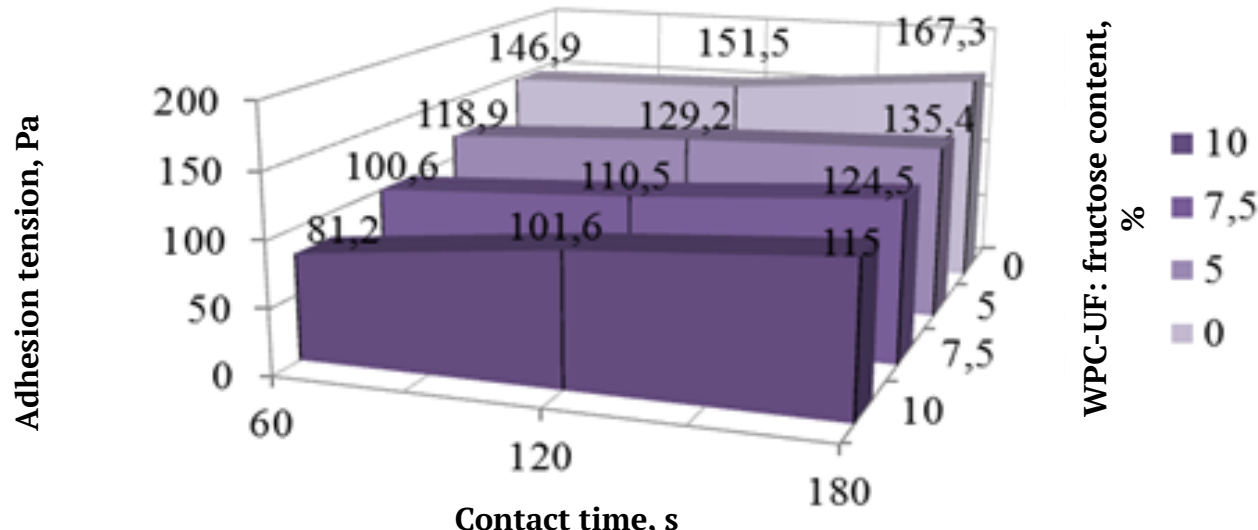

Fig. 3. Dough adhesion stresses vs different concentrations of the model system WPC-UF: fructose 1:2

Source: own development

The study of dough specimen adhesion showed that the value of adhesion tension is significantly influenced by the time of cpecimen contact with the equipment working element. The WPC-UF: fructose model system decreases adhesion tension.

Fig. 3 shows that adhesion decreases with the WPC-UF: fructose model system increase. Introducing 5\% WPC-UF:fructose model system into the formulation decreased adhesion 1,2 times as compared to control specimen; adding $7.5 \%$ 
WPC-UF:fructose model system decreased adhesion 1.5 times; 10\% WPC-UF:fructose model system decreased adhesion almost 2 times. These data show improvement in dough quality.

The carried out experiments and analysis of the obtained data were the basis for developing the recepe of gero-dietetic muffins.

Tab.1. Dough adhesion tension vs different concentrations of the WPC-UF: fructose model system

\begin{tabular}{|c|c|c|c|c|}
\hline \multirow{2}{*}{ Contact duration, sec } & $\begin{array}{c}\text { Contact duration, } \\
\text { sec }\end{array}$ & \multicolumn{3}{|c|}{ Contact duration, sec } \\
\cline { 2 - 5 } & $\mathbf{0}$ & $\mathbf{5}$ & $\mathbf{7 , 5}$ & $\mathbf{1 0}$ \\
\hline 60 & 146,9 & 118,9 & 100,6 & 81,2 \\
\hline 120 & 151,5 & 129,2 & 110,5 & 101,6 \\
\hline 180 & 167,3 & 135,4 & 124,5 & 115 \\
\hline
\end{tabular}

Source: own development

The technology of gero-dietetic muffins consists in the following processing: the carrot puree is prepared - boiled carrots are scrubbed and blended into uniform puree. The required quantity of WPC-UF is mixed with fructose in the proportion of $1: 2$; the system is then mixed with eggs, sunflower oil, walnuts. Then salt, flour, and leavening agents are added. The forms are filled at the level of $1 / 3$ with some carrot puree added inside. Baking is at $180^{\circ} \mathrm{C}$ for $6-7$ minutes. The dough is carefully kneaded. The mass is then put into the oiled form at the level of $2 / 3$ with the mixture of currot puree and fructose inside. The time of baking is $6-8$ minutes at $180^{\circ} \mathrm{C}$. The recipe of the gero-dietetic muffin "Dobrolit" is given in Table 2. The new technology of the gero-dietetic muffins contains sources of protein, microelements and macroelements, vitamins reaching $2-53 \%$ of the daily demands, i.e. it is characterized by higher biological activity and meets the requirements of gero-dietetic food recipe (protein: fats: carbohydrates $=1: 0.8: 4.7)$.

Tab. 2. Project of the "Dobrolit" gero-dietetic muffin recipes

\begin{tabular}{|l|c|c|l|}
\hline \multirow{2}{*}{ Name of raw materials } & \multicolumn{2}{|c|}{ Cupcake «Blue» } & \multirow{2}{*}{$\begin{array}{c}\text { Technological requirements to } \\
\text { the quality of raw materials }\end{array}$} \\
\cline { 2 - 3 } & gross & net & ГОСТ 7975-68 \\
\hline Carrot & 17 & 11 & ГОС \\
\hline Wheat flour & 20 & 20 & ГОСТ 26574-85 \\
\hline KSB-UV & 15 & 15 & ДСТУ 4273 \\
\hline Fructose & 23 & 23 & ТУ У 51.1-2841802819-001-2001 \\
\hline Protein (egg) & 20 & 20 & ГОСТ 52751-2003 \\
\hline Walnut Oil & 4 & 4 & ТУ У 24239615-003-97 \\
\hline Sunflower oil & 2 & 2 & ДСТУ 4492 \\
\hline Ripper & 1,5 & 1,5 & ТУ У 302722099.018-2000 \\
\hline Salt & 0,3 & 0,3 & ДСТУ 3583 \\
\hline Weight semi & - & 125,8 & \\
\hline Output & - & 100 & \\
\hline
\end{tabular}

Source: own development 


\section{Conclusions and results discussion}

The results of the carried out research make it possible to have the product which meets the requirements of the gero-dietetic food formula. The study of the influence of the whey proteins concentrate obtained by ultrafiltration with fructose helped us make these conclusions:

1. The use of the whey protein concentrate composition which were obtained by ultrafiltration with fructose in the technology of geto-dietetic confectionary goods enriches confectionary goods with protein and make the product which is adequate for elderly people.

2. The research made it possible to extend the gero-dietetic confectionary product range; wich will improve food for elderly and old people. The developed gero-dietetic muffins can be used in the diet of those who are over 60 for disease prevention as well as for general health improvement. The scientific novelty is in the study of laws for the processes of making multicomponent model compositions of confectionatygooods using whey proteins concentrate obtained by ultrafiltration with fructose.

3. Practical importance of the obtained results is the introduction of the developed confectionary products in the nutrition of elderly and old people in restaurants and establishments of social protection in Ukraine.

4. The perspectives of further research will advance the system of early ageing prevention in Ukraine.

\section{REFERENCES}

Cherevko, O.I. (Ed.). (2017). Innovatsiini tekhnolohii kharchovoi produktsii funktsionalnoho pryznachennia [Innovative technologies of food products of functional purpose]. Kharkiv: KhDUKhT [in Ukrainian].

Hryhorov, Yu.H., Povorozniuk, V.V., Korzun, V.N., Podrushniak, A.Ye., Semesko, T.M., Synieok, L.L., \& Hryhorieva, N.V. (2006). Ratsionalne kharchuvannia liudei litnoho i starechoho viku [Rational nutrition for people of elderly and old age]. Kyiv: Znannia [in Ukrainian].

Lysiuk, H.M. (Ed.). (2007). Tekhnolohiia kondyterskykh i khlibobulochnykh vyrobiv [Technology of confectionery and bakery products]. Kharkiv: KhDUKhT [in Ukrainian].

Lysiuk, H.M. (Ed.). (2009). Tekhnolohiia boroshnianykh kondyterskykh i khlibobulochnykh vyrobiv [The technology of flour confectionery and bakery products]. Sumy: Universytetska knyha [in Ukrainian].

Morley, J.E., \& Thomas, D.R. (Eds). (2007). Geriatric Nutrition. NY: CRC Press [in English].

Proceedings of 11-th International Congress on Engineering and Food "Food Process in Changing World". (2011). Athens: NTUA, School of Chemical Engineering [in English].

Rostovskyi, V.S., Dorokhyna, M.O., \& Polozhyshnykova, O.Y. (1988). Ispolzovanie vtorichnogo syrja na predprijatijah obshhestvennogo pitanija [The using of secondary raw materials in catering]. Kyiv: Tekhnika [in Russian].

Svidlo, K.V. (2010). Pererozpodil vody u bezdrizhdzhovomu tisti z BAD mikrovodorosti ta yoho mikrostruktura [Redistribution of water in the non-yeast dough from the supplemented microalgae and its microstructure]. In Obladnannia ta tekhnolohii kharchovykh vyrobnytstv [Equipment and technology of food production] (pp. 109-114). Donetsk: Donetskyi natsionalnyi universytet ekonomiky i torhivli imeni Mykhaila Tuhan-Baranovskoho [in Ukrainian]. 


\section{УДК 664.68:637.142.2]:613.2-053.9}

\section{Карина Свідло,}

доктор технічних наук,

Харківський торговельно-економічний інститут

Київського національного торговельно-

економічного університету,

Харків, Україна,

karinasvidlo@gmail.com

http://orcid.org/0000-0002-0175-7756

\section{ІННОВАЦЙНІ ТЕХНОЛОГІЇ КОНДИТЕРСЬКИХ ВИРОБІВ ГЕРОДІЄТИЧНОГО ПРИЗНАЧЕННЯ З ВИКОРИСТАННЯМ ВТОРИННОЇ МОЛОЧНОЇ СИРОВИНИ}

Актуальність. Процес створення нової галузі харчової промисловості - виробництва геродієтичних продуктів - важливий у кількох аспектах: широке впровадження геродієтичних продуктів у фактичному харчуванні літніх і старих людей дозволить виправити недоліки харчування сучасної людини; використання геропродуктів надзвичайно важливо в плані лікувального харчування та для профілактики передчасного старіння. Мета і методи. Метою статті є обгрунтування використання композиції концентрату сироваткових білків, отриманих шляхом ультрафільтрації з фруктозою в технології кондитерських виробів геродієтичного призначення. Метод визначення кількості та якості сирої клейковини, що використаний у дослідженні, відповідає ISO 21415-2:2015 Wheat and wheat flour Gluten content - Part 2: Determination of wet gluten and gluten index by mechanical means. Адгезійне напруження тістових мас від впливу різної концентрації модельної системи КСБ-УФ: фруктоза проводили на розривній машині MT-140 / RV2. Результати. Наведені дані дослідження впливу концентрату сироваткових білків, отриманих шляхом ультрафільтрації (КСБ-УФ) у системі з фруктозою, на властивості кексового тіста та проведена на підставі цих даних розробка інноваційної технології кексів геродієтичного призначення. Висновки та обговорення. Використання композиції концентрату сироваткових білків, отриманих шляхом ультрафільтрації з фруктозою в технології кондитерських виробів, дозволяє отримати продукцію, що відповідає формулі геродієтичного харчування. Розроблені кекси геродієтичного призначення можливо використовувати в раціоні людей старше 60 років як для профілактики захворювань, так і для загального оздоровлення організму.

Ключові слова: геродієтична продукція, технологія кондитерських виробів, вторинна молочна сировина, концентрат сироваткових білків, отриманих шляхом ультрафільтрації, фруктоза. 


\section{УДК 664.68:637.142.2]:613.2-053.9}

\section{Карина Свидло,}

доктор технических наук,

Харьковский торгово-экономический институт Киевского национального торгово-экономического университета, Харьков, Украина, karinasvidlo@gmail.com

http://orcid.org/0000-0002-0175-7756

\section{ИННОВАЦИОННЫЕ ТЕХНОЛОГИИ КОНДИТЕРСКИХ ИЗДЕЛИЙ ГЕРОДИЕТИЧЕСКОГО НАЗНАЧЕНИЯ С ИСПОЛЬЗОВАНИЕМ ВТОРИЧНОГО МОЛОЧНОГО СЫРЬЯ}

Актуальность. Процесс создания новой отрасли пищевой промышленности - производства геродиетических продуктов - является важным в нескольких аспектах: широкое внедрение геродиетических продуктов в фактическом питании пожилых и старых людей позволит исправить недостатки питания современного человека; использование геропродуктов чрезвычайно существенно в плане лечебного питания и для профилактики преждевременного старения. Цель и методы. Целью исследования является обоснование использования композиции концентрата сывороточных белков, полученных путем ультрафильтрации с фруктозой, в технологии кондитерских изделий геродиетического назначения. Метод определения количества и качества сырой клейковины, использованный в исследования, соответствует ISO 21415-2: 2015 Wheat and wheat flour - Gluten content Part 2: Determination of wet gluten and gluten index by mechanical means. Адгезионное напряжение тестовых масс от влияния различной концентрации модельной системы КСБ-УФ: фруктоза проводили на разрывной машине MT-140 / RV2. Результаты. Приведены данные исследования влияния концентрата сывороточных белков, полученных путем ультрафильтрации (КСБ-УФ) в системе с фруктозой, на свойства кексового теста и проведена на основании этих данных разработка инновационной технологии кексов геродиетического назначения. Выводы и обсуждение. Использование композиции концентрата сывороточных белков, полученных путем ультрафильтрации с фруктозой в технологии кондитерских изделий, позволяет получить продукцию, соответствующую формуле геродиетического питания. Разработанные кексы геродиетического назначения можно использовать в рационе людей старше 60 лет как для профилактики заболеваний, так и для общего оздоровления организма.

Ключевые слова: геродиетическая продукция, технология кондитерских изделий, вторичное молочное сырье, концентрат сывороточных белков, полученных путем ультрафильтрации, фруктоза. 